\title{
Life - Skill Based Learning to Improve Early Childhood Child Creativity
}

\author{
Sri Sumiyati1, Aini Indriasih ${ }^{1}$, Sumaji ${ }^{2}$ \\ 1 Universitas Terbuka, Indonesia \\ 2 Universitas Muria Kudus, Indonesia
}

\begin{abstract}
Early child independency spurs creativity improvement. Essentially, independency is caused by educational effort by implementing life - reliability education since early childhood. This quasiexperimental research with pretest and posttest design covered learning scenario arrangement to find out the initial condition of children before the intervention. Initially, an assessment in the form of behavioral test was done randomly and was observed. Self - reliability learning promotion assisted by media and the already prepared real activity through various games which were designed by the researcher and teachers. The subjects consisted of B group students taken by total sampling. It was all population taken into the sample, consisting of 26 children. The data collection was done by using two collecting instruments: observation and documentation. Before being tested on the respondent, the data were tested to ensure the reliability of the instruments' functions as well as to check the validity and reliability of the instrument. The data were analyzed statistically by a comparative test. The findings showed there was a difference of creativity improvements between pre and post-intervention and observation during the learning process. There was a strong relationship between pre and post-training and observation, which influenced life - reliability to improve creativity.
\end{abstract}

Keywords: life skill, early children, creativity

This is an open access article under the CC-BY-NC license.

\section{INTRODUCTION}

Early childhood child education is important for both family and nation. It is an important investment for the national future and for the sake of a more advanced state. In other words, the future of a nation depends on the obtained education by the children. Therefore, early childhood child education is a valuable national investment. To prepare them with life skill education is also important. The skills are useful for their next study and their future mature life. However, the facts show that many children, after they are adults, do not have skills. Thus, they have difficulties getting job or to create job opportunities.

Early childhood education has an important role in later child development because early childhood education is an essential foundation of a child's personality. A child who receives early childhood guidance will have his independency improved, and he could optimize his potency (Anik Pamilu, 2007). Early childhood education is acknowledged as an important period in developing human resources, and it only has one shot and could never be repeated (Bredekamp et al., 1997).

Early childhood or preschool ages are the Golden Age. It is indicated by quick development in physical, cognitive, social, and emotional developments (Nurani Yuliani 2012). Therefore, to 
undergo this age properly, there is a need for appropriate education for early children. Furthermore, various studies stated that early childhood had all intelligence aspects such as intellectuality, emotion, and spirituality developed enormously (Agustin, Mubiar dan Syaodih, Ernawulan (2008).

Along with various development, early children as learners require the teacher to be more creative and less boring, so it could motivate their development (Mislaini, 2017). Therefore, teachers should find suitable learning for their development. Furthermore, the roles of teachers in delivering learning for early children should consider developmental stages and sensitive moments of students. Learning early children should be addressed to construct life skills instead of cognition.

Early childhood education should be addressed to foster life skills instead of cognitive skills (Yuni Rachmawati dan Kurniati, 2012). Life skill improvements for children are needed to make them able in coping with all daily needs, such as having a meal, drinking, taking a bath, wearing clothes, using sandals, and using shoes without parents' assistance. The learning process is done to provide a meaningful basic concept for them through real experience, allowing them to show activities and curiosity optimally. Then, teachers should put themselves as companion, advisor, and facilitator for them. This educational process could avoid any learning-oriented on teacher's intention dominantly and put the students passively (Nurani Yuliani, 2011).

Life skill education becomes a different approach to apply by considering this education has benefits for students, such as academic and vocational skills, and so forth. The problem is how educational institution could apply it so it could facilitate students obtaining useful life skill which is needed in students' daily life (Mislaini, 2017). Life skill education is an alternative to active, creative, and joyful learning.

Studies concerning life skills have been frequently conducted. They are such as Cahyaningrum et al. (2014), Ajik and Soeryanto (2016), and Usman (2010). The findings were such as (1) significant correlations were found among personal life, social, academic, and vocational skills of toward the wielding practicum learning outcome of Trenggalek 1 Public Vocational High School learners. (2) The study showed that the personal skills in cycle I obtained a percentage of $51.3 \%$, categorized average based on lower information organization skills. The second cycle obtained a percentage of $79.3 \%$, categorized excellent based on the information organization skill through discussion. In the third cycle, it improved to $90.3 \%$, categorized very excellent as reflected from their collective decision-making to solve problems (Ajik and Soeryanto, 2016). (3) Life skill training could eradicate poverty, especially for those dropouts (Usman, 2010). From the results, reviews about life skill education with creativities on important matters were still limited. In fact, having creativity could trigger various ideas and notions. Thus, having creativity could facilitate an individual's life in the future after graduating from school and getting into society. 
Life skill education should be developed as early as possible. There are three life skill categories: social and interpersonal, cognitive, and emotional copying skills (Maddaleno and Infante, 2001:54). Through this mastered life skill, it is expected for them to survive and to have responsibility. Life skill learning is purposed to make children being able to manage themselves (self-help) and to help other people (social skill) as care realization and social responsibility as a member of family and society (Catron and Allen, 1999:205).

Various efforts are needed to consider by all involved parties in the educational process. They are family, school, and society. At last, by having creativity, an individual could have sufficient preparation to develop life skills (Astuti \& Irene, 2003). Life skills are broader than early childhood creativity.

Habitualizing creativity operationally means to construct a society that sees creativity as "good" and being not creative is "not good." It makes creativity into habit; figures, idols, society, and the youths are creative people; and respecting creativity as an important, meaningful, and useful matter (Rake, 1998:8).

The educational world on early childhood needs child creativity development because it could be a preparation for them to be more motivated, more independent, and more proactive in facing changing process in developing educational concept oriented to a life skill (Astuti \& Irene, 2003).

Astuti \& Irene (2003) explained that creativity is the initial stage in giving basic life skills to children. Thus, they will be braver to face life problems and live normally without being stressed. Then, proactively and creatively, they could find a solution to reach a successful life.

Based on the background, the research problem is - does life skill influence early child creativity improvement, and how great does it influence?

The hypothesis of life-skill based learning is - it influences the early childhood students' creativities in Prambatan Lor Kindergarten.

\section{RESEARCH METHODOLOGY}

The subjects were A-group students consisting of 26 children. They were studying in Pertiwi Prambatan Lor Kindergarten, Kudus Municipality. The sampling technique is total sampling. The population is taken as the sample, consisting of 26 children. The data collection techniques apply two main data collection instruments. They are observation and documentation studies. The observation is purposed to observe the students' activities in joining the learning activity. This quasi-experimental research with one-group pretest and posttest designs was chosen because this research compared pre and post-intervention without a control group. As Sugiyono 
(2010) argued, a one-group pretest-posttest design could be done by comparing pre and postintervention conditions. The research variables were life skills and early child creativity education.

The subjects of the research were 26 A group of students learning at TK Pertiwi Prambatan Lor, Kudus municipal. The technique of sampling was total sampling by taking all population as the sample, consisting of 26 students. This total sample was used because all the population in this study were used fatherly analyzed, out of 26 children, all met the requirements for further analysis. The data collection was done by two main data collecting instruments: observation and documentary study. The observation was carried out by giving the first skill instrument to students, and then students were trained by the teacher after there was exercise, the students were given the second skill instrument. Then the researcher sees the difference after being trained and before there is training. Documentation studies are conducted by researchers to strengthen the results of research obtained from literature studies and previous research. Meanwhile, the measuring scale was rating scale by this calculation: 4 - Very well developed (BSB), 3 - expectedly developed (BSH), 2 - beginning to develop (MB), and 1 - is not developed (BB).

Before testing the data to the respondent, there was a need to test the instrument functions to find out its validity and reliability. The data analysis was done by statistics data analysis through a comparative test. It measured students' creativities between pre and post-intervention and observation. Before being analyzed with a comparative test, a hypothesis test was needed with precondition and classical assumption tests in the form of normality and heteroscedastic tests. This test is conducted to believe that the data obtained does not have biased data, which will result in research results that do not reflect the actual conditions. The hypothesis test was done by t-test to find out the partial correlation of independent variable to the dependent variable, f-test to find out the correlation between the variables simultaneously, and multiple linear regression test to find out the contribution of the independent variable to dependent variable. The reason for choosing this type of research and technical analysis is because the researcher wants to know whether there are differences before and after treatment using the training method and to find out how much influence the training method has on children's creativity. In judging the creativity, it was done by filled by teachers and parents by looking at their works during learning at the school.

\section{FINDINGS AND DISCUSSION}

In this research, the used early childhood demography data were ages, genders, and class groups on kindergarten with the data of Table 1 . There were 26 subjects. The students' creativities were measured by an instrument consisting of 15 questions on the observation. 
Table 1. Respondent Profile (N = 26)

\begin{tabular}{lcc}
\hline \multicolumn{1}{c}{ Remarks } & $\begin{array}{c}\text { Numbers of } \\
\text { Students }\end{array}$ & $\begin{array}{c}\text { Percentage } \\
(\%)\end{array}$ \\
\hline Genders & & \\
M & 12 & 46.2 \\
F & 14 & 53.8 \\
Ages & & \\
5 & 21 & 80.8 \\
6 & 5 & 19.2 \\
Kindergarten Group & & \\
B & 26 & 100 \\
\hline
\end{tabular}

Inquiry, observation, and statement indicators were tested on early childhood children at Pertiwi Prambatan Lor Kudus kindergarten for each item on the given observation for creativity variable seen in Table 2 . The table also presents average changes of pre-and post-intervention and observation on early children who became an observational object in this research.

Table 2. Pre- and Post- Results

\begin{tabular}{|c|c|c|c|c|c|}
\hline Indicators & No & Indicator/Observation & $\begin{array}{l}\text { Pretest } \\
\text { Mean }\end{array}$ & Mean & \\
\hline \multirow{3}{*}{$\begin{array}{l}\text { Curiosity in } \\
\text { the classroom }\end{array}$} & K1 & Frequently asking in the class & 1.6923 & 2.7692 & \\
\hline & $\mathrm{K} 2$ & $\begin{array}{l}\text { Sharing opinion or notion } \\
\text { based on the material }\end{array}$ & 1.6154 & 2.6538 & \\
\hline & K3 & Doing the task well & 1.9615 & 3.0769 & \\
\hline \multirow{3}{*}{$\begin{array}{l}\text { High } \\
\text { originality }\end{array}$} & $\mathrm{K} 4$ & $\begin{array}{l}\text { Being brave to defend } \\
\text { notion/opinion }\end{array}$ & 1.6154 & 2.5769 & \\
\hline & K5 & $\begin{array}{l}\text { Creating outstanding } \\
\text { masterpiece }\end{array}$ & 1.7692 & 2.9231 & \\
\hline & K6 & $\begin{array}{l}\text { Working with less assistance } \\
\text { of teachers }\end{array}$ & 1.9615 & 2.9231 & \\
\hline \multirow{3}{*}{ Imaginative } & K7 & $\begin{array}{l}\text { Telling the already done } \\
\text { activities }\end{array}$ & 1.7308 & 2.9231 & \\
\hline & K8 & Expressing new notions & 1.4615 & 2.5385 & \\
\hline & K9 & Executing an action & 1.6538 & 2.8077 & \\
\hline \multirow{3}{*}{$\begin{array}{l}\text { Art } \\
\text { Appreciation }\end{array}$} & K10 & $\begin{array}{l}\text { Making of various forms of } \\
\text { activities }\end{array}$ & 1.8462 & 2.8846 & \\
\hline & K11 & Properly speaking & 2.1923 & 3.1538 & \\
\hline & K12 & Having initiation & 1.5385 & 2.6538 & \\
\hline \multirow{3}{*}{$\begin{array}{l}\text { Being brave to } \\
\text { take risk }\end{array}$} & K13 & $\begin{array}{l}\text { Being brave to admit the } \\
\text { mistakes }\end{array}$ & 1.7308 & 2.6923 & \\
\hline & K14 & Being brave to accept task & 1.8077 & 3.0385 & \\
\hline & K15 & Solving current problem & 1.6154 & 2.8077 & 0.4915 \\
\hline
\end{tabular}

Source: Observational Question List, 2019

Table 2 explains that the number of question items in creative observation consisted of 15 questions with creativity indicators before training and observation. The observation result before 
the training showed that the lowest observation on imaginative nature and sharing new notion indicators had an average score of 1.4615. Meanwhile, in Table 2, the highest score was on the appreciation art indicator and properly speaking indicator with an average 2.1923.

After having observation and training, generally in Table 2, all indicators improved significantly. It could be concluded that after intervention and observation, there was a positive influence on training and observation so they could develop as expected in doing the tasks.

The observational result after being trained showed the lowest observation was on the curiosity indicator. Being brave to defend notion/opinion obtained 2.5769. Although it obtained the lowest score, it also showed expected development. The highest observation was on appreciation art indicator with early childhood observation in properly speaking with 3.1538 . Therefore, it could be known that children had developed as expected properly

\section{Data Validity Test}

The test was done to find the validity of each question item in measuring the variables. The validity test was done by correlating each score of question item addressed for the respondent with the total score for all items. The correlating technique to test the validity of questions in this research was the Pearson Product Moment. If the coefficient of the tested question item was higher than r-critical 0.2746 , then it could be concluded that the question item was valid construction. Here is the validity result, as presented in Table 3.

Table 3. Validity Test Result of Variable

\begin{tabular}{lrrc}
\hline Question Number & r-count & r-table & Remarks \\
\hline Cre1 & 1 & 0.2746 & Valid \\
Cre2 & $.571^{* *}$ & 0.2746 & Valid \\
Cre3 & 0.281 & 0.2746 & Valid \\
Cre4 & $.630^{* *}$ & 0.2746 & Valid \\
Cre5 & $.453^{*}$ & 0.2746 & Valid \\
Cre6 & $.557^{* *}$ & 0.2746 & Valid \\
Cre7 & $.528^{* *}$ & 0.2746 & Valid \\
Cre8 & $.506^{* *}$ & 0.2746 & Valid \\
Cre9 & 0.382 & 0.2746 & Valid \\
Cre10 & $.412^{*}$ & 0.2746 & Valid \\
Cre11 & $.510^{* *}$ & 0.2746 & Valid \\
Cre12 & $.393^{*}$ & 0.2746 & Valid \\
Cre13 & $.497^{* *}$ & 0.2746 & Valid \\
Cre14 & 0.304 & 0.2746 & Valid \\
Cre15 & 0.326 & 0.2746 & Valid \\
\hline
\end{tabular}

**. Correlation is significant at the 0.01 level (2-tailed).

*. Correlation is significant at the 0.05 level (2-tailed).

As stated in the table, when the correlative coefficient was equal to the critical correlation coefficient $(r$-table $=0.2746$ ) or higher, the instrument number was said valid. The table shows that 
the correlative coefficient of all instrument numbers of research variables was higher than the $r$ table. Therefore, the instrument was said valid, so the questions of the questionnaires could be used for further investigation.

\section{Reliability Test}

The reliability test was done for all question numbers were categorized as valid. The reliability test was done by testing the instrument once then was analyzed by using Alpha Cronbach. The questionnaire was said reliable, positive, and greater than 0.8 . Here is the reliability test as shown in Table 4

Table 4. Reliability Test Result of Research Variable

\begin{tabular}{cc} 
Cronbach's Alpha & N of Items \\
\hline .944 & 30 \\
\hline
\end{tabular}

Table 4 summarizes the reliability test. It is known that Cronbach Alpha on the variable was higher than 0.924 . The findings could be concluded that all instruments were reliable and could be used for further analysis. It meant the questionnaire was consistent if it was measured in a different time, model, or design.

\section{Classical Assumption Test}

Normality Test

The use of parametric statistics worked by the assumption that each research variable which would be analyzed should be normal. If it was not normal, then the parametric statistics technique could not be used to analyze, but non-parametric statistics could be used. Therefore, before using parametric statistics analysis, it was important to test the data with a normality test to find out whether the data were normally distributed or not.

Table 5. Normality Test Result

\begin{tabular}{llr}
\hline & & Creativity \\
\hline $\mathrm{N}$ & & 26 \\
Normal & Mean & 42.4231 \\
Parameters & Std. Deviation & 5.96773 \\
Most Extreme & Absolute & .192 \\
Differences & Positive & .113 \\
& Negative & .192 \\
Kolmogorov-Smirnov Z & .981 \\
Asymp. Sig. (2-tailed) & .291 \\
\hline
\end{tabular}


This research used one-sample Kolmogorov-Smirnov (KS) by looking at the significance level. If the significant level is beyond 0.05 , then the variables are normally distributed. The normality test in Table 5 for the research variable showed Asymp Sig (2-tailed) was 0.981 for creativity. It was higher than 0.05 ; thus, the variables were normally distributed.

\section{Heterosedasisity Test}

Table 6 showed that pre- and post- intervention/observation consisted of 26 data. The average between pre- and post- observation/trainings was 26.19 and 42.42, respectively. The standard deviation before the training was 4.792, while after the intervention was 5.968 .

Table 6. Heterosedasisity Test Result

\begin{tabular}{llcrrr}
\hline & & \multicolumn{4}{c}{ Std. } \\
& & Mean & N & neviatio & Std. Error \\
& & Mean \\
\hline Pair 1 & Pretest_Creativity & 26.19 & 26 & 4.792 & .940 \\
& & & & & \\
& Posttest_Creativity & 42.42 & 26 & 5.968 & 1.170 \\
\hline
\end{tabular}

Table 6 shows the average of pretest creativity was $26.19<$ posttest 42.4 . Then, descriptively, there were creativity average changes between pretest and posttest.

\section{Creativity Variable Before and After the Treatment and Observation}

The data analysis of this research was meant to find out the correctness of the formulated hypotheses. It was to find out the influence of the implementation of life - skill-based learning to improve early child creativity. Then, to find out the existence of influences using Paired Sample TTest. The analysis of Paired -Sample T-Test is a procedure used to compare two variables in a group. It meant the analysis was useful to test toward two correlating or pairing samples. Paired Sample $T$-Test procedures were used to test whether two-variable differences. The data could be from two measurements of the same subjects or one measurement with several subjects.

Table 6 shows each pre- and post- treatment/observation was 26 . The average score of preobservation/treatment was 26.19 , while post treatment was 42.42 . The standard deviation before the treatment and observation was 4.792, and after the treatment was 5.968 .

Table 7. Pretest and Posttest Correlation of Creativities

\begin{tabular}{|c|c|c|c|c|}
\hline & & $\mathrm{N}$ & Correlation & Sig. \\
\hline $\begin{array}{l}\text { Pair } \\
1\end{array}$ & $\begin{array}{l}\text { Pretest_creativity \& } \\
\text { Posttest_creativity }\end{array}$ & 26 & .689 & .000 \\
\hline
\end{tabular}

The table, paired sample correlation table, consists of data that had a correlation between pre-and post- influences of life skill to improve creativity. It was 0.689 with a sig score of 0.000 . It showed that there was the influence of life skills to improve creativity. By looking at this result, it 
showed that the correlation was $0.689>0.000$. The correlation was higher than the sig score. It showed there was the influence of life skills to improve creativity. The next step was answering the second problem formulation about how far life skills are influenced to improve creativity. It was done by looking at Table 8 . The correlation result was 0.689 . It showed the correlation of life skills to improve creativity was sufficient.

Table 8. Nilai Koefisien Coefficient Score

\begin{tabular}{lcl}
\hline No & Correlational Coefficient & Explanation \\
\hline 1 & Between $0.800-1.000$ & High \\
2 & Between $0.600-0.800$ & Sufficient \\
3 & Between $0.400-0.600$ & Little bit poor \\
4 & Between $0.200-0.400$ & Poor \\
5 & Between $0.000-0.200$ & Very poor \\
\hline
\end{tabular}

Table 9 shows the results of the two-sample t-test consisting of $t$-count and significance with a score of -18.915. The next step was to check the life skill influence to improve creativity.

Table 9 T-test

\begin{tabular}{|c|c|c|c|c|c|c|c|c|c|}
\hline & & \multicolumn{8}{|c|}{ Paired Differences } \\
\hline & & \multirow[t]{2}{*}{ Mean } & \multirow[t]{2}{*}{$\begin{array}{c}\text { Std. } \\
\text { Deviation }\end{array}$} & \multirow[t]{2}{*}{$\begin{array}{l}\text { Std. Error } \\
\text { Mean }\end{array}$} & \multicolumn{2}{|c|}{$\begin{array}{l}95 \% \text { Confidence } \\
\text { Interval of the } \\
\text { Difference }\end{array}$} & \multirow[t]{2}{*}{$\mathrm{T}$} & \multirow[t]{2}{*}{ df } & \multirow[t]{2}{*}{$\begin{array}{l}\text { Sig. (2- } \\
\text { tailed) }\end{array}$} \\
\hline & & & & & Lower & Upper & & & \\
\hline Pair 1 & $\begin{array}{l}\text { Pretest_Creati } \\
\text { vity- } \\
\text { Posttest_creati } \\
\text { vity }\end{array}$ & -16.231 & 4.375 & .858 & -17.998 & -14.463 & -18.915 & 25 & .000 \\
\hline
\end{tabular}

Source: Primary Processed Data, 2019

The data could be concluded that t-count was -18.915 with sig 0.00 . Since sig $<0.001$, it could be concluded that Ho was denied. It meant the creativity average of early children before and after observation and training had a significant difference. Therefore, it could be stated that the observation and training influenced the creativity of early students of TK Pertiwi Prambatan Lor, Kudus, significantly.

\section{CONCLUSION}

Based on the life-skill based implementation reflection to improve the early childhood students' creativities, the researcher found several suggestions to apply this method and for further investigations. First, it deals with difficulties to control the respondents. It happened because the ones that filled the instruments were not the real respondents but the teachers and the students' parents instead of the kindergarten students. They did it by observing the children's behaviors. 
Second, this research applies questionnaire. It had bias perception possibilities upon the questions because the ones that filled it were not the students but the parents and the teachers based on their mere observation. Further research is expected to apply the experimental method to avoid any perceived bias. Third, follow-up research after research, which is longitudinal in nature to measure the students' creativities after the intervention, could be carried out by using other methodologies, such as a direct interview for the kindergarten students or ensuring the further educational party. Fourth, based on the findings, it could be seen that the improvement of the investigated students' creativity could be further studied by using other variables, such as student motor skills, etc.

\section{REFERENCES}

Aji, S dan Soeryanto (2016). Pengintegrasian Pendidikan Kecakapan Hidup (Life Skills Education) DI SMK PGRI 5 Surabaya untuk Meningkatkan Kecakapan Personal Siswa. JPTM. 4 (3).

Anik, Pamilu. 2007. Mengembangkan Creativitas dan kecerdasan anak. Jakarta: Buku kita

Astuti, D., \& Irene, S. (2003). Pengembangan Kecakapan Hidup (Life Skill) Melalui Penanaman Etos Kerja dan Membangun Creativitas Anak. Cakrawala Pendidikan, 3(1).

Cahyaningrum, S. N., Sutadji, E., \& Solichin, S. (2014). Hubungan Between Life Skills Siswa Dengan Hasil Belajar Praktikum Pengelasan di SMKN 1 Trenggalek. JURNAL TEKNIK MESIN, 21(2).

Mislaini, M. (2017). Pendidikan Dan Bimbingan Kecakapan Hidup (Life Skill) Peserta Didik. Tarbawiyah Jurnal Ilmiah Pendidikan, 1(02), 88-101.

Agustin, Mubiar dan Syaodih, Ernawulan (2008). Bimbingan Konseling untuk Anak Usia Dini. Jakarta. Universitas Terbuka.

Catron, Carol.E dan Jan Allen. (1999). Early Childhood Curriculum: ACreative Play Model, 2nd Edition.NewJersey: Merill Publ.

Hurloch, Elizabet (2010). Perkembangan anak, jilid 2; alih bahasa Meitasari Tjandrasa. Jakarta: Erlangga

Maddaleno, Matilde dan Francisca Infante. (2004) Life Skills Approach toChild and Adolescent Healthy. USA: Pan American Health Organization.

Nurani Yuliani (2011) Konsep Dasar Pendidikan Anak Usia Dini. Jakarta: PT Indeks

Rachmawati, Y dan Kurniati, E (2012). Strategi Pengembangan Creativitas Pada Anak Usia Taman Kanak-kanak. Jakarta: Kencana Prenada Media.

Sugiyono. (2010). Statistika Untuk Penelitian. Bandung: Alfabeta.

Wahyudin, Dkk, 2007. Pengantar Pendidikan. Jakarta: Universitas Jakarta

Usman, H. (2010). Model Pendidikan Kecakapan Hidup Sebagai Alternatif Mengurangi Angka Kemiskinan. (17) 1. 7-14 